\title{
Modeling the relationship between the big five personality traits and resilience, considering self-esteem as a mediator variable
}

\author{
Mitra Vaghar Hasanpur ${ }^{1}$, Yousef Jalali ${ }^{2}$, Masumeh Tayebli ${ }^{3}$ \\ 1-MA in Psychology \& Education of Exceptional Children, Department of Psychology, Allameh Tabataba'i \\ University, Tehran, Iran (Corresponding Author). $\quad$ E-mail: mitra.vaghar1991@gmail.com \\ 2- PhD in Psychology, Department of Psychology, Allameh Tabataba'i University, Tehran, Iran. \\ 3- PhD in Psychology \& Education of Exceptional Children, Department of Psychology, Allameh Tabataba'i \\ University, Tehran, Iran.
}

Received: $31 / 05 / 2020 \quad$ Accepted: 03/08/2020

\begin{abstract}
Introduction: Resilience is a dynamic process that helps people cope with life's stressful issues effectively.

Aim: The objective of present study was to test the theoretical model of relationship between the big five personality traits and resilience, considering self-esteem as a mediator variable.

Method: The research method was descriptive-correlational. The statistical population included all men and women aged 18 and over in District 6 of Tehran in 2018. The research sample consisted of 252 citizens aged 18 to 64 years who were selected by the convenient sampling method. Of these, 154 were male and 98 were female. The instruments were Connor-Davidson Resilience Inventory (2003), Rosenberg Self-Esteem Scale (1965) and NEO-FFI (1985). The research data were analyzed by the Pearson correlation and path analysis methods.

Results: The results of path analysis method indicated that self-esteem only mediates the relationship between neuroticism, extraversion and agreeableness with resilience. To be more precise, agreeableness had only an indirect effect $(\mathrm{P}<0.001)$, conscientiousness had only a direct effect $(\mathrm{P}<0.05)$, neuroticism and extraversion had both direct and indirect effects $(\mathrm{P}<0.001)$, and openness to experience had no significant effect on resilience $(\mathrm{P}>0.15)$.

Conclusion: According to the results, paying attention to variables such as neuroticism, extraversion, agreeableness, conscientiousness and self-esteem which affect resilience, as well as self-esteem as a mediator of the relationship between neuroticism, extroversion and agreeableness with resilience, can lead to a better understanding of the relationship between these variables.
\end{abstract}

Keywords: Big five Personality, Resilience, Self-esteem

How to cite this article : Vaghar Hasanpur M, Jalali Y, Tayebli M. Modeling the relationship between the big five personality traits and resilience, considering self-esteem as a mediator variable. Shenakht Journal of Psychology and Psychiatry. 2020; 7 (4): 78-92 .URL: http://shenakht.muk.ac.ir/article-1-930-en.pdf

Copyright $\odot 2018$ the Author (s). Published by Kurdistan University of Medical Sciences. This is an open access article distributed under the terms of the Creative Commons Attribution-Non Commercial License 4.0 (CCBY-NC), where it is permissible to download, share, remix, transform, and buildup the work provided it is properly cited. The work cannot be used commercially without permission from the journal. 


\title{
مدل يابى روابط ميان ينج عامل بزرك شخصيت و تابآورى، بادر نظر كرفتن عزت نفس به عنوان متغير ميانجى
}

\author{
ميترا وقار حسن يور'، يوسف جلالى '، معصومه طيب لى \\ ا.كارشناس ارشد روانشناسى و آموزش كود كان استثنائى، گروه روانشناسى، دانشخاه علامه طباطبائى، تهران، ايران (مولف مسئول). \\ mitra.vaghar1991@gmail.com : ايميل \\ ז. دكترى تخصصى روانشناسى، گروه روانشناسى، دانشگاه علامه طباطبائى، تهران، ايران. \\ r. دكترى تخصصى روانشناسى و آموزش كود كان استثنائى، گرووه روانشناسى، دانشگًاه علامه طباطبائى، تهر ان، ايران.

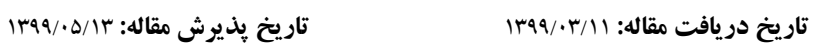

جكکبه مقدمه: تاب آورى فرايندى بويا است كه باعث مىشود افراد با مسائل تنيدگىزاى زندگى به طور كار آمدى كنار بيايند. هدف: آزمون مدل نظرى رابطه ميان ينج عامل بزرگك شخصيت و تاب آورى با ميانجى گرى عزت نفس، هدف مطالعه حاضر بود. روش: روش ثرٔوهش، توصيفى از نوع همبستخى بود. جامعه آمارى شامل كليه مردان و زنان \1 سال به بالاى منطقه 4 شهر تهران در

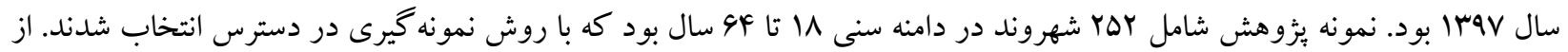

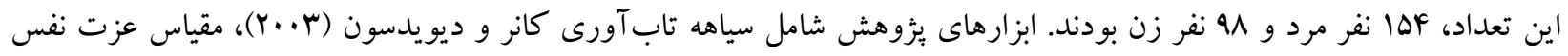

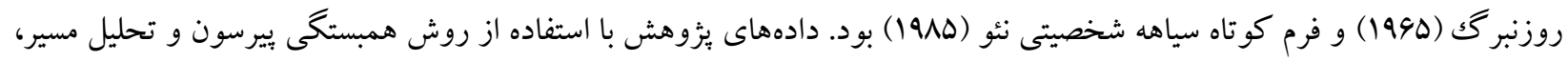
تجزيه و تحليل شدند.

يافتهها: نتايج حاصل از روش تحليل مسير نشان داد كه عزت نفس فقط در رابطه روان رنجورخويى، برون گرايى و خوشايندى با

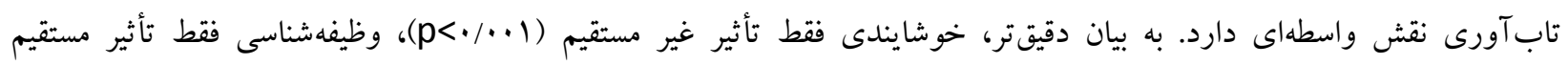

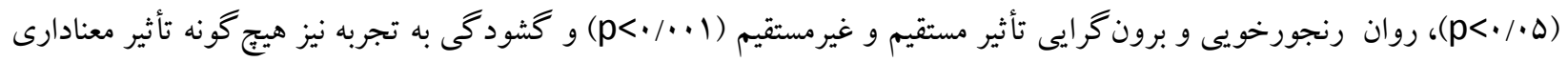

$$
\text { بر تابآورى نداشت (p>-1/D). }
$$

نتيجه كيرى: براساس نتايج حاصل از يُروهش، توجه به متغيرهايى جون روان رنجورخويى، برون گرايى، خوشايندى، وظيفهشناسى و

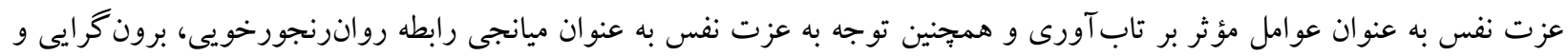
خوشايندى با تابآورى، مى تو اند به درك بيشتر رابطه ميان متغيرهاى مذكور بينجامد. كليدوازهها: ينج عامل بزرگك شخصيت، تابآورى، عزت نفس 
تعريف مى كنند. ينج عامل شخصيتى معرفى شده توسط

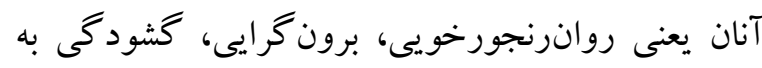
تجربه، خوشايندى و وظيفه شناسى به عنوان ويزگ

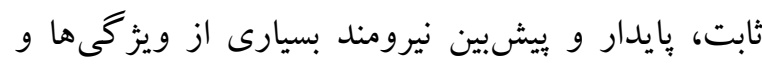
رفتارهاى افراد قلمداد شدهاند و تاب آورى نيز به عنوان يك عامل محافظت كننده، متأثر از اين ويز كىهاى شخصيتى دانسته شده است (اوشيو، تاكو، هيرانو و و

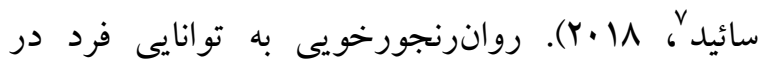
تحمل تنيدگى مربوط مىشود. افراد داراى سطوح بالاى روانرنجورخويى ثبات هيجانى پايينى دارند. اين افراد

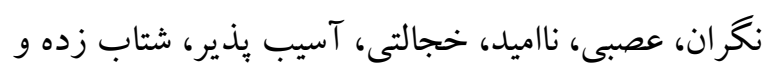
داراى تنيدگى هستند. همجنين اين افراد اغلب هيجانهاى

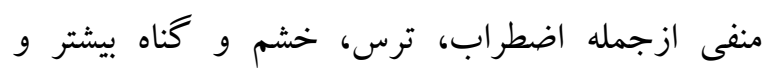
شديدترى را تجربه مى كنند (مكك كرى و كاستا، 19AV). منظور از برون گرايى درجهاى است كه شخص بر انرزى، معاشرتى، جسور، فعال، هيجان طلب و داراى شور و شوق، اعتماد به نفس و احساسات مثبت است. افراد برونگرا تمايل به اجتماعى بودن، احساسى بودن و

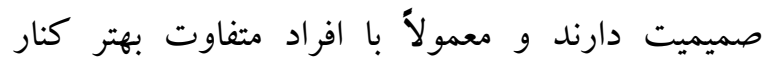

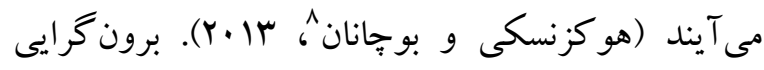

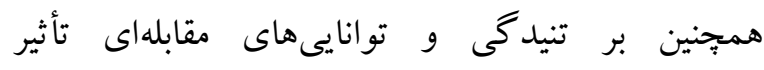

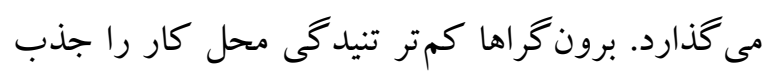
مى كنند و ممكن است واقعاً در محل كار جالش انخيز نيز با راهبرد حل مسئله و جستجوى راههاى جديد براى

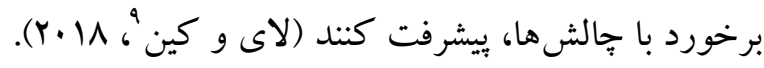
كشودگى به تجربه، ميزان علاقه افراد نسبت بهتاز خى و و كسب تجارب جديد را نشان مىدهد. افراد داراى سطوح بالاى گشودگى به تجربه داراى قدرت تخيل بالا،

7- Oshio, Taku, Hirano \& Saeed

${ }^{8}$ - Huczynski, \& Buchanan

${ }^{9}$ - Lai \& Qin
شواهد يُزوهشى نشان مىدهد كه تاب آورى به عنوان

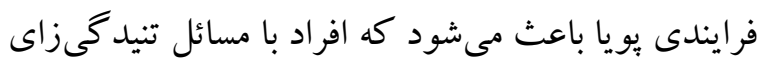
زندگى بهطور كار آمدى كنار بيايند. تاب آورى افسردگى

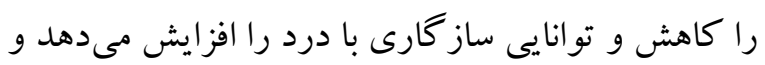
علاوه بر اين، كيفيت زندگى را بالا مىبرد (وايت، درايور

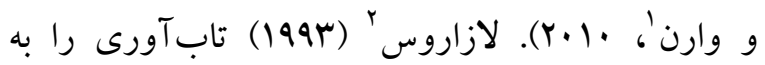
عنوان ظرفيت افراد براى مقاومت كردن در برابر سختىها، باز گشتن از ناملايمات و حركت به به سوى زندكى سالم تو أم با رفاه و خوشى در آينده تعريف كرده

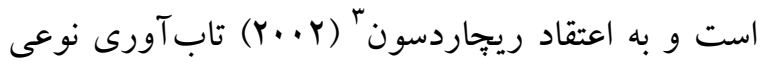
ظرفيت كلى است كه افراد براى به حداقل رساندن مشكلات و غلبه بر آنها از آن استفاده مى كنند

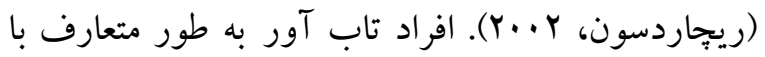
ويز كىهايى جون منبع كنترل درونى، خودانگاره مثبت، خوشينى، مقابله فعالانه، سرسختى و خود كارآمدى تونى

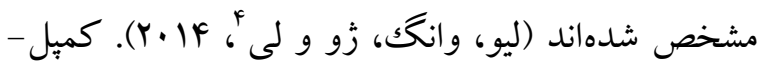

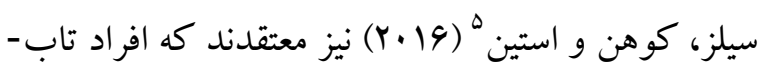
آور توانايى ايجاد و گسترش مجموعهاى از مهارتهاى

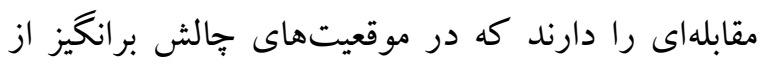
آنها محافظت مى كند. اين نكته نيز آشكار شده است كه تفاوتهاى شخصيتى نقش تعيين كنندهاى در بروز واكنشهاى متفاوت افراد در برابر تنشهاى روانى دارند. در همين راستا، كاستا و مكك كرى " (1994) عوامل شخصيت را به عنوان ابعاد تفاوتهاى فردى در تمايل به نشان دادن الكوهاى بايدار افكار، احساسات و رفتارها

\footnotetext{
1. White, Driver \& Warren

2 - Lazarus

3 - Richardson

4- Liu, Wang, Zhou \& Li

5. Campbell-Sills, Cohan, \& Stein

6. Costa \& McCrea
} 
نفس را به عنوان يكك متغير واسطهاى مهم مطرح كردهاند. بثزوهشها نشان مىدهد كه عزت نفس يكى از مهم ترين عوامل روانشناختى مؤثر بر سلامتى است كه اشاره به

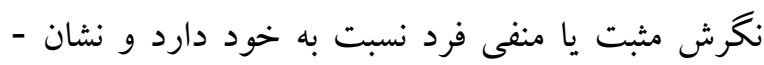

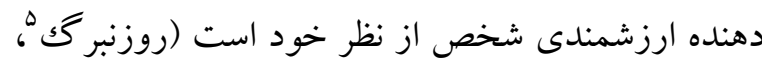
1990). به زبان ساده عزت نفس احترامى است كه فرد براى خود قائل مىشود و نشان دهنده ظرفيت فرد براى دريافت عشق و احترام است (جوهار، ايشاكك و زين

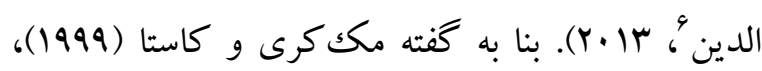
عزت نفس ارتباط بسيار نزديكى با صفات شخصيتى دارد.

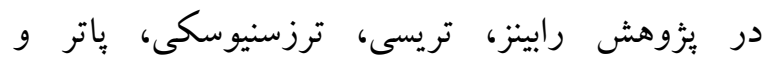
كاسلينگ از واريانس عزت نفس را تبيين كردند و صفاتى جون روانرنجورخويى، برون گرايى و وظيفه شناسى بيشترين رابطه را با عزت نفس داشتند. همجنين، در يُزوهش لوكى

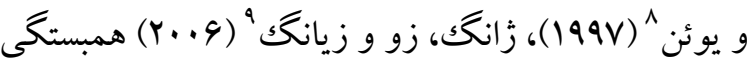
متوسط تا ضعيفى ميان وظيفه شناسى، گشودگى به تجربه و عزت نفس مشاهده شده است. ساير مطالعات نيز از

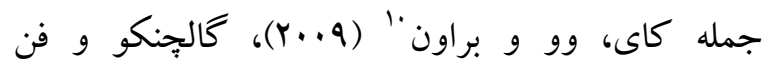

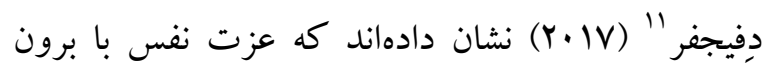

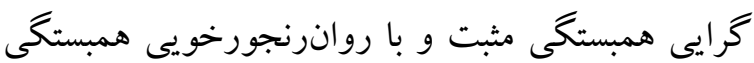
منفى دارد. علاوه بر اين، نتايج برخى مطالعات ازجمله

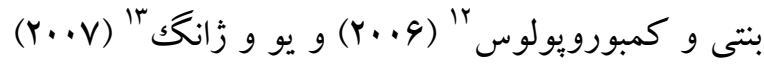
حاكى از وجود رابطه معنادار ميان عزت نفس و و تابآورى است. در همين راستا، نتايج مطالعه پياركک،

\footnotetext{
${ }^{4}$ - Kwan, Bond \& Singelis

5 - Rosenberg

6. Johar, Ishak, \& Zainudin

7- Robins, Tracy, Trzesniewski, Potter \& Gosling

${ }^{8}$ - Luk \& Yuen

9- Zhang, Zou \& Xiang

${ }^{10}$ - Cai, Wu \& Brown

${ }^{11}$ - Galchenko, \& Van de Vijver

${ }^{12}$ - Benetti \& Kambouropoulos

${ }^{13}$ - Yu \& Zhang
}

احساسات باز، علاقه به جلوههاى هنرى، كنجكاو نسبت به ايدهاى ديكران، بعلاوه اقدام گرا و داراى ايده هستند (اسودى كرمانى، اشرفيان، زينالى، ايمانى و شبانلوئى،

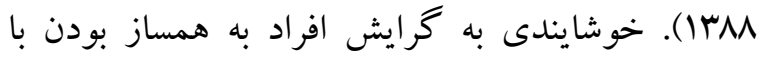

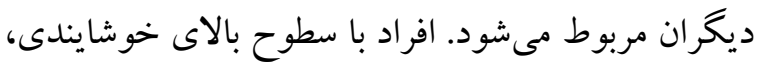
قابلاعتماد، روراست، نوع دوست، مهربان، مطيع، متواضع، خوشقلب و داراى خصيصه ازخود كذشتكى هستند. (هو كزنسكى و بو جانان، سا •YY). وظيفه شناسى نيز معيار سنجش قابليت اطمينان است. فرد با سطوح بالاى وظيفه شناسى، فردى شايسته، منظم، وظيفه شناس، هدف جو، داراى انضباط شخصى، وقت شناس و قابل اتكا است

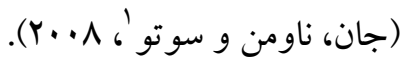

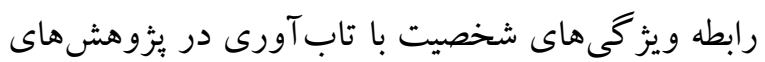
متعددى تأييد شده است. براى مثال، كميل-سيلز و و

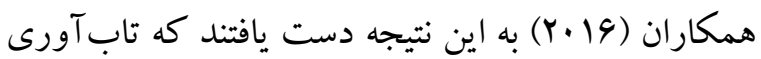
با روانرنجورخويى همبستگى منفى و با برون گرايى و

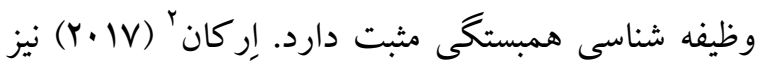
نشان داد كه ركههاى شخصيت ازجمله وظيفهشناسى،

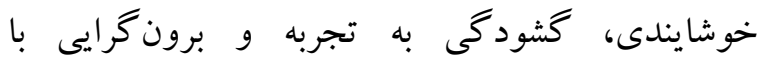
تابآورى رابطه مستقيم و مثبت و با روانرنجورخويى رابطه منفى و معكوس دارند. با اينحال، اينكه جّكونه ويز گىهاى شخصيت و تابآورى به يكديخر مرتبط مىشوند و مكانيسمهايى كه رابطه اين دو متغير را ميانجى گرى مى كنند تا حدودى ناشناخته است. به همين دليل بررسى نقش متغيرهاى واسطهاى در رابطه بين ويز گیىاى شخصيت و تابآورى حائز اهميت است. برخى يزوهشهاى اين حوزه ازجمله شى، ليو، يانگك و

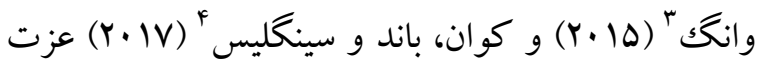

\footnotetext{
1- John, Naumann \& Soto

2- Ercan

3- Shi, Liu, Yang, \& Wang
} 
توضيحات لازم درباره هدف يزوهش و جلب رضايت آكاهانه آنها، ابزارهاى بثزوهش به ترتيب تصادفى در اختيار آنها قرار داده شد و از آنها در خواست گرديد كه ضمن قيد كردن سن، جنسيت و تحصيلات خود در برسشنامها، در نهايت دقت و صداقت آنها را تكميل نما يند. معيارهاى ورود به بثروهش عبارت بود از: رضايت آكاهانه جهت شركت در يثزوهش، دارا بودن تحصيلات

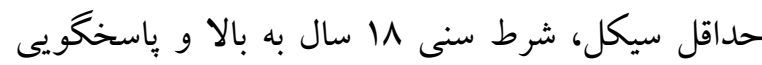
كامل به هر سه يرسشنامه يُزوهش. معيارهاى خروج از يخوهش نيز شامل تحصيلات يايين تر از سيكل، سن كمتر

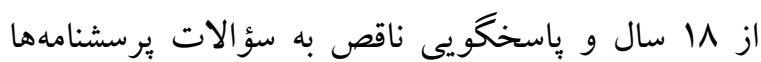
بود. در مرحله بعد، بر اساس معيارهاى ورود و خروج،

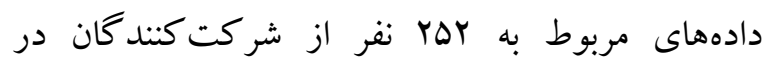
يُوهش وارد تحليل گرديد. از اين تعداد،

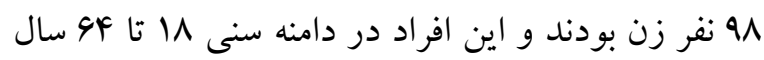
قرار داشتند. در نهايت، دادههاى حاصل از اجراى "يزوهش از طريق آمارهاى توصيفى جون ميانگين، انحراف استاندارد و همبستكى ييرسون و آمارهاى استنباطى جون تحليل مسير و با استفاده از نرمافزار AMOS

ابزار به منظور جمع آورى اطلاعات از ابزارهاى زير استفاده سياهل تابآورى: سياهه تابآورى 'با مرور منابع يزوهشى 19V9-1991 توسط كانر و ديويدسون (r... تهيه شد. اين سياهه شامل ها مادّه است و براى اندازهكيرى قدرت مقابله با استرس تهيه شده است. براى هر

\footnotetext{
${ }^{1}$ - Resilience Conner \& Davidson Inventory (CD-RISC)
}

كيم، ياركك، سوه و لى' (Y.19) نيز نشان مىدهد كه عزت نفس از انسان در برابر اضطراب محافظت مى كند، شيوههاى مقابله را بهبود مىبخشد، سلامت جسمانى را افزايش مىدهد و افراد را نسبت به آسيب پيذيرى آكًاه مى كند. با همه اين اوصاف، به احتمال نسبتاً زياد هيج يُزوهشى نقش واسطهاى عزت نفس را در رابطه ميان عو امل شخصيتى و تاب آورى بررسى نكرده است؛ اما در يرتو همبستكى عزت نفس با ويز گیى هاى شخصيت و تاب آورى، بيشبينى مىشود كه عزت نفس رابطه ميان ويز گىهاى شخصيت و تاب آورى را ميانجى گرى كند؛ لذا با توجه به بيشينه يزوهش مى تو ان كفت كه رابطه ميان عوامل شخصيتى و تابآورى صرفاً يكى رابطه خطى ساده نيست و متغيرهاى ديخر مى توانند بهعنوان ميانجى اين رابطه را تحت تأثير قرار دهند. ازاينرو، هدف مطالعه حاضر، آزمون مدل نظرى رابطه بين بنج عامل بزرك شخصيت و تاب آورى با ميانجى گرى عزت نفس بود.

\section{روش}

مطالعه حاضر از لحاظ هدف بنيادى و از لحاظ ماهيت توصيفى از نوع همبستخى است. جامعه آمارى شامل كليه مردان و زنان \1 سال به بالاى منطقه 9 شهر تهران در سال V9 1 ا بود. دليل انتخاب منطقه 9 اين است كه يكك منطقه ميانى در شهر تهران محسوب مىشود و تنوع ساكنين آن از نظر متغيرهاى زمينهاى بيشتر به نظر مىرسد. بر اساس بر آورد يارامترهاى موجود در مدل، تعداد •و ن نفر (191)

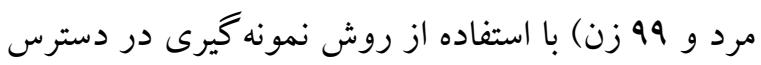
از مكانهاى عمومى سطح شهر از جمله بوستانها،

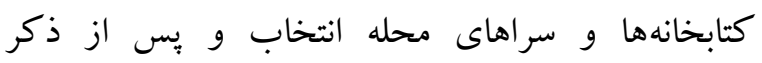

\footnotetext{
1. Park, Kim, Park, Suh \& Lee
} 


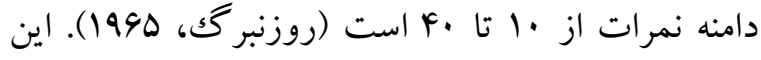
مقياس ضرايب همبستگى قوى ترى نسبت به سياهه عزت نفس كوير اسميت دارد و در سنجش سطوح عزت نفس داراى روايى بيشترى است و واجد اعتبار و روايى همخرا

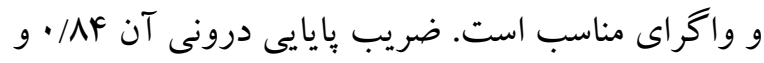

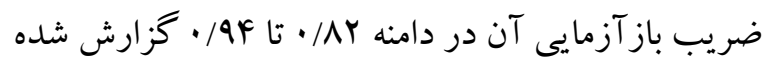

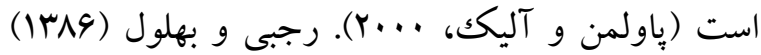
نيز براى بررسى ويثز گهاى روانسنجى مقياس مذكور با اجر اى آن بر روى دانشجويان و استفاده از تحليل عاملى

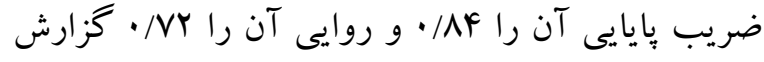
كردهاند.

فرم كوتاه سياهه شخصيتى نئوّ! اين فرم در سال هـ19 توسط كاستا و مكك كرى تهيه شده است و داراى يكك فرم كوتاه ·4 مادّهاى است كه NEO-FFI ناميده مىشود. اين سياهه شامل ه زيرمقياس روانرنجورخويى،

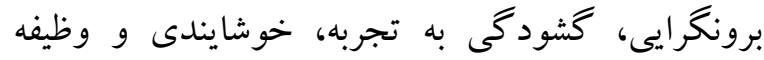

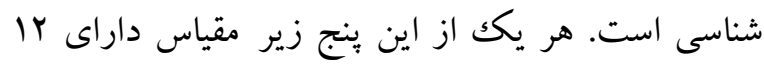

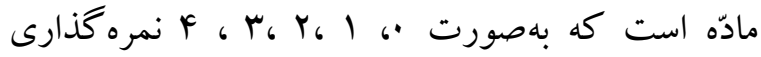
مىشود. تعدادى از مادّها به طور معكوس نمرهذذارى

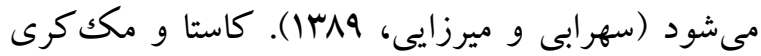

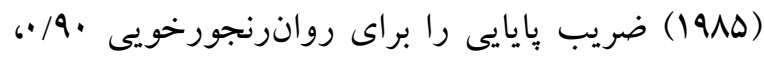

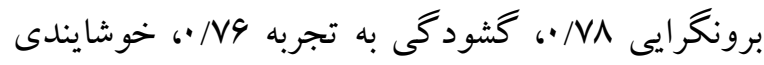

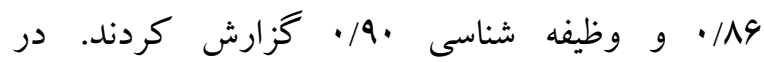
هنجاريابى آزمون NEO كه توسط كروسى فرشى

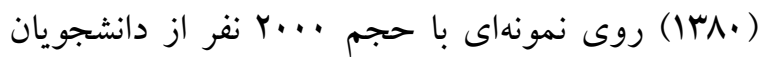
دانشگاههاى تبريز، شيراز و دانشگاههاى علوم بز شكى اين دو شهر صورت گرفت، ضريب همبستخى ه بعد اصلى

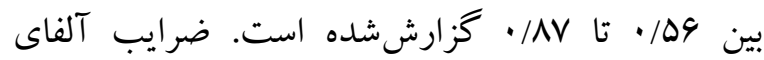

\footnotetext{
${ }^{2}$ - NEO-Five Factor Inventory (NEO-FFI)
}

مادّه يكك طيف درجهبندى ينج گزينهاى (كاملاً نادرست تا هميشه درست) در نظر كرفته شده كه از صفر (كاملاً نادرست) تا جهار (هميشه درست) نمره گذارى مىشود. اين سياهه اگرجهه ابعاد مختلف تابآورى را مىسنجد ولى داراى يكك نمره كل است (كانر و ديويدسون، r... (Y). يايايى سياهه به روش باز آزمايى و آلفاى كرونباخ و روايى آن به روش تحليل عوامل و روايى همخرا و واگرا توسط سازندگان در گرووهاى مختلف (بالينى و غير بالينى) محاسبه شده است. ضريب بايايى همسانى درونى اين سياهه از طريق آلفاى كرونباخ در دامنه V9/.

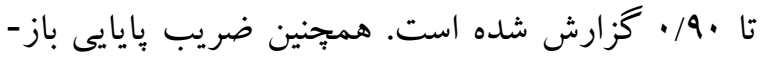
آزمايى اين سياهه |N/· به دست آمده است (كانر و

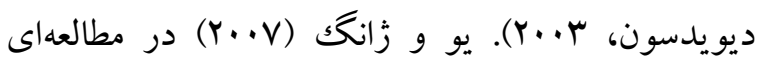
ويز گیىهاى روانسنجى اين سياهه را مطلوب گزارش

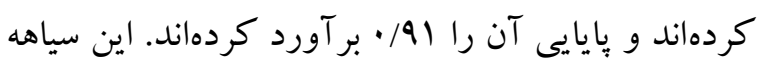
در ايران توسط محمدى، جزايرى، رفيعى، جوكار و

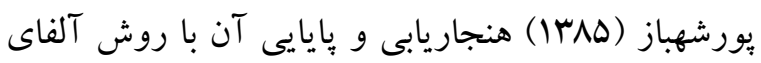

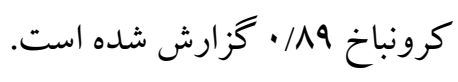
مقياس عزت نقس روزنبرك: مقياس عزت نفس روزنبر گ' در سال 1990 توسط موريس روزنبر گك تهيه و معرفى شد. اين مقياس · ا مادّه دارد كه عزت نفس كلى كلى را اندازه كيرى مى كند. به نظر ياولمن و آليك (.... مقياس عزت نفس روزنبر گ يكى از رايجترين مقياس-

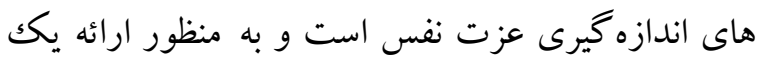
تصوير كلى از بازخوردهاى مثبت و منفى درباره خود ساخته شده است (نقل از رضايى، بيانى و شريعت نيا،

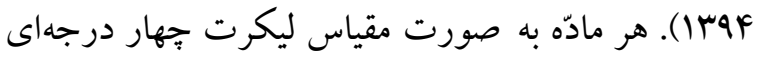
از كاملاً موافق تا كاملاً مخالف نمره گذارى مى مى بهود.

\footnotetext{
${ }^{2}$ - Rosenberg Self-Esteem Scale (RSES)
} 
تحصيلات) نشان داد كه افراد داراى مدرك ليسانس (4/111) ساله (L/DF

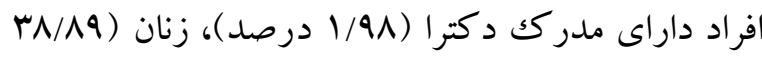
درصد) و افراد ·F-F ساله (V/K4 درصد) كمترين نسبت از نمونه يُوهش را تشكيل مىدهند. همجنين، ميانگين سنى نمونه يزٔوهش بعدى، شاخصهاى توصيفى ازجمله ميانگين، انحراف

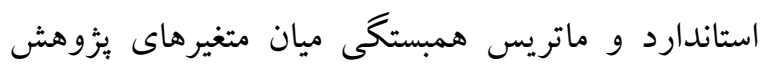
محاسبه شده است. نتايج حاصل از بررسى ميانگين و انحراف استاندارد متغيرها در جدول ا نمايش داده شده

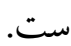

كرونباخ در هر يكك از عوامل اصلى روانرنجورخويى، برونگرايى، گشودگى به تجربه، خوشايندى و وظيفه شناسى به ترتيب 19/•، سV/ •، 49 •، 191/ و و • • به

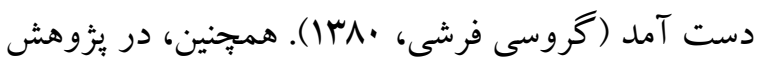
آتشروز (9N1) با استفاده از روش همسانى درونى، ضريب آلفاى كرونباخ براى ركههاى روانرنجورخويى، برونگرايى، گشودگى به تجربه، خوشايندى و وظيفه شناسى به ترتيب /VF/ •،

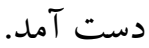

\section{يافتهها} در بخش نخست، نتايج حاصل از بررسى متغيرهاى جمعيت شناختى نمونه يزوهش (سن، جنسيت و سطح

\begin{tabular}{|c|c|c|}
\hline انحر اف استاندارد & ميانكين & جدول ا ميانتين \\
\hline$F / W$ & rQ/NY & عزت نفس \\
\hline $1 Y / 91$ & $48 / 19$ & تاب آورى \\
\hline $9 / 94$ & $r q / 9 \Delta$ & روانرنجورخويى \\
\hline $9 / 0$. & $r \mid / r r$ & برونكرايى \\
\hline$\Delta / M$ & $r \cdot / 9 r$ & كشود \\
\hline$\Delta / r \Delta$ & $r \cdot / q$. & خوشايندى \\
\hline $9 / 9 \mathrm{~V}$ & $r Q / \Lambda 1$ & وظيفه شناسى \\
\hline
\end{tabular}

ميانگين عزت نفس در حد متوسط، ميانگين تابآورى اندكى بايينتر از متوسط و ميانخين تمامى ركههاى شخصيت نيز اندكى بالاتر از متوسط است. اطلاعات حاصل از محاسبه همبستگى وييرسون بين متغيرهاى يثوهش ارائه شده است. اين اطلاعات در جدول r قابل مشاهده است.
جدول ا ميانگين و انحراف استاندارد متغيرهاى يثوهش را نمايش مى دهد. با توجه به اينكه بيرسشنامهاى مورداستفاده در مطالعه حاضر ظاهراً در داخل كشور هنجاريابى نشده و ميانگين آنها مشخص نخرديده؛ لذا نمىتوان درباره نتايج به دست آملده تفسير دقيق و معتبرى ارائه داد. تنها مىتوان كفت كه با توجه به ميانگين فرضى يرسشنامهاى مذكور، در آزمودنىهاى مطالعه حاضر، 


\begin{tabular}{|c|c|c|c|c|c|c|c|}
\hline$r$ & 9 & $\Delta$ & $p$ & $r$ & $r$ & 1 & متغير \\
\hline & & & & & & - & عزت نفس \\
\hline & & & & & - & $\cdot / A r^{* * * * *}$ & ناب آورى \\
\hline & & & & - & $-\cdot / 91^{* * * * *}$ & $-\cdot|\wedge|^{* * *}$ & روانرنجورخويى \\
\hline & & & - & $-\cdot / \mathscr{F} \Lambda^{* * * * *}$ & $\cdot / N^{N^{* * * * *}}$ & $\cdot / F F^{*}$ & برونترايى \\
\hline & & - & $\cdot / \Lambda^{* * * *}$ & $-\cdot / Y \Delta^{*}$ & $\cdot / \Lambda f^{* * * *}$ & $\cdot / \Delta \Delta^{*}$ & كشودىى \\
\hline & - & $\cdot / r r^{*}$ & $\cdot / r q^{*}$ & $-\cdot / \Psi^{* *}$ & $\cdot / V r^{* * * * *}$ & $\cdot / r \Delta^{*}$ & خوشايندى \\
\hline- & $\cdot / r V^{* * *}$ & $\cdot / Y F^{*}$ & $\cdot / r 9^{*}$ & $-\cdot|F|^{*}$ & $\cdot / \mathrm{V}^{* \text { ***** }}$ & $.101^{*}$ & وظيفه شناسى \\
\hline
\end{tabular}

$\mathrm{P}<\cdot / \cdot \Delta^{*} \quad \mathrm{P}<\cdot / \cdot 1 * *$

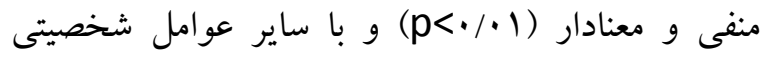
رابطه مثبت و معنادار (1) آزمون مدل نظرى يزٔوهش از روش تحليل مسير استفاده شد كه نتايج حاصل از آن در جدول با و شكل ا نمايش
همان گونه كه در جدول r مشاهده مىشود، عزت نفس رابطه مثبت و معنادار با تاب آورى ( (1+>) م) برون-

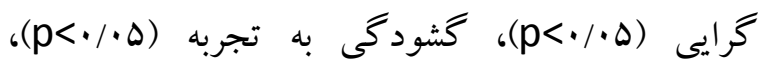

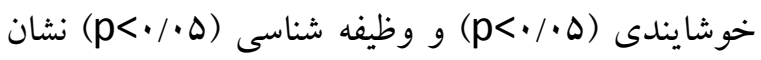
مىدهد و با روانرنجورخويى رابطه منفى و معنادار (1) (1) دارد. تاب آورى نيز با روانرنجورخويى رابطه

\begin{tabular}{|c|c|c|c|c|}
\hline سطح معنادارى & $\mathbf{t}$ & Beta & B & مدل \\
\hline.$/ \cdot 1$ & $-1 \cdot / 1 \mathrm{~V}$ & $-1 / \cdot 1$ & $-\cdot / V r$ & مسير روانرنجورخويى به عزت نفس \\
\hline$\cdot / \cdot 1$ & $r / r)$ & $\cdot|4|$ & $\cdot / \mu$ & مسير برونكر ايى به عزت نفس \\
\hline.$/ \cdot 1$ & $F / V q$ & .194 & $\cdot / \Delta \Delta$ & مسير خوشايندى به عزت نفس \\
\hline ه.r/. & $-1 / \cdot r$ & $-\cdot / 1 V$ & $-\cdot / l f$ & مسير كشود كى به عزت نفس \\
\hline - TOQ & $1 / 14$ & $\cdot /$ F &.$/ 1$ & مسير وظيفه شناسى به عزت نفس \\
\hline.$/ \cdot 1$ & $\Delta / V \Delta$ & . & - /AF & مسير عزت نفس به تاب آورى \\
\hline.$/ 101$ & $1 / F r$ & $\cdot / 11$ & $\cdot / 41$ & مسير كشودحى به تاب آورى \\
\hline$\cdot / \cdot \Delta$ & $1 / 9 r$ & r/I & $\cdot / r \Delta$ & مسير وظيفه شناسى به تاب آورى \\
\hline$\cdot / \cdot \operatorname{kr}$ & $r / \cdot r$ &.$/ 19$ & $\cdot / 41$ & مسير برونكرايى به تاب آورى \\
\hline$\cdot \cdots 1$ & $-F / \mu \Lambda$ & 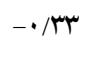 & $-\cdot 194$ & مسير روانرنجورخويى به تاب آورى \\
\hline$\cdot / V 91$ & $\cdot / \mu$ & $\cdot / \cdot r$ & .1 .9 & مسير خوشايندى به تاب آورى \\
\hline
\end{tabular}




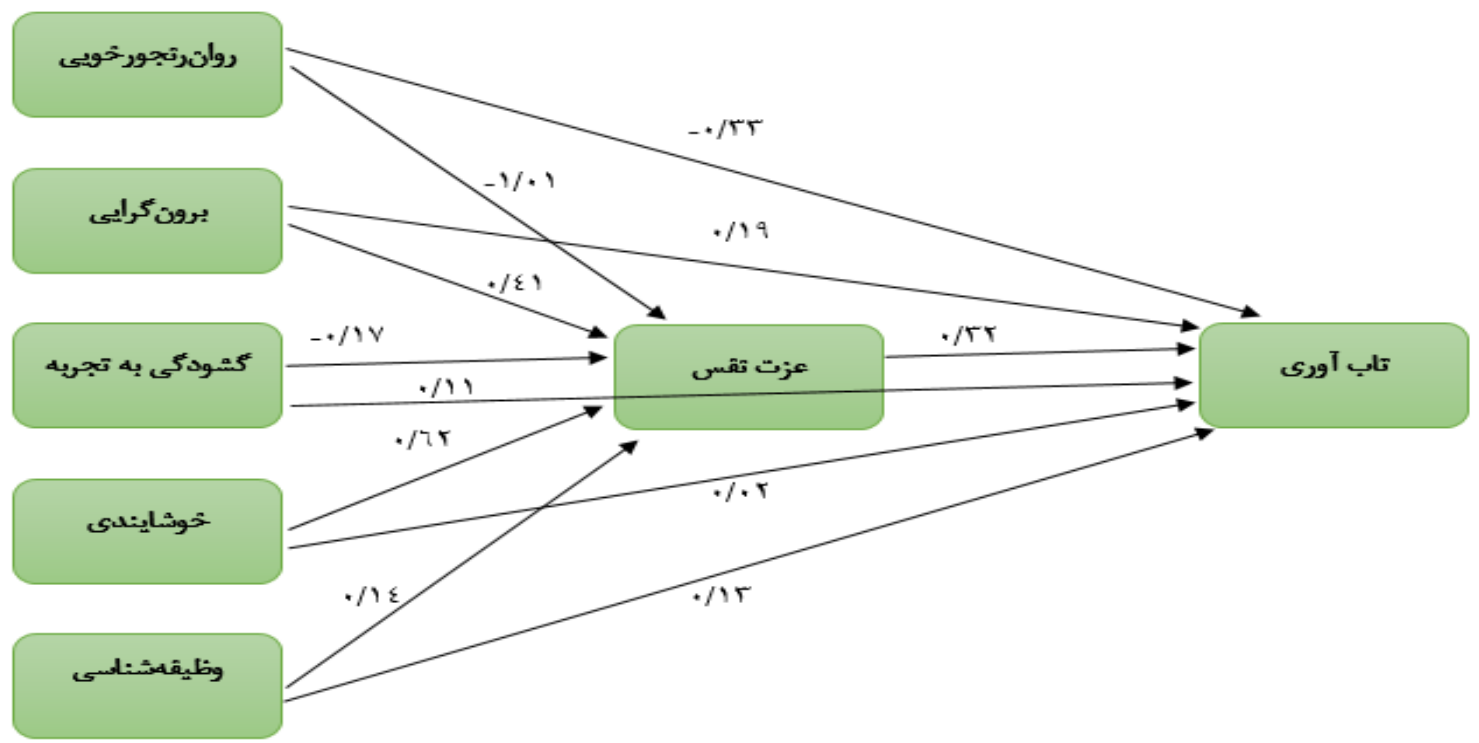

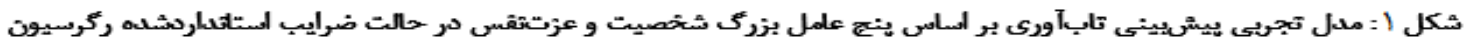

(p>r/ro) معنادار در مدل تجربى، جهت دستيابى به يك مدل مناسب و داراى برازش، ضرايب غير معنادار حذف شدند و مدل اوليه يزوهش اصلاح گرديد. نتايج حاصل از مدل اصلاح شده در جدول r و شكل r ارائه شده است.
همان گونه كه نتايج موجود در جدول rو شكل ا نشان

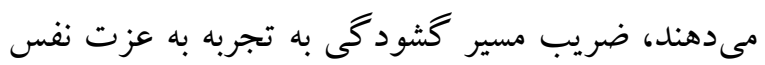

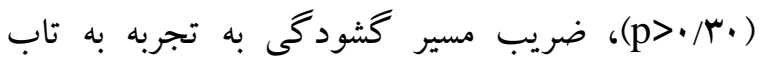

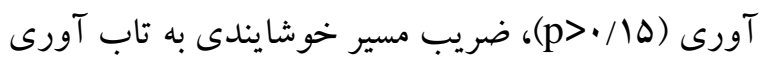
و ضريب مسير وظيفه شناسى به عزت نفس (p>-/V9)

\begin{tabular}{|c|c|c|c|c|}
\hline سطح معنادارى & $\mathbf{t}$ & Beta & $\mathbf{B}$ & مدل \\
\hline.$/ \cdot 1$ & $-|F / 9|$ & $-1 / \cdot 1$ & $-\cdot / V Y$ & مسير روانرنجورخويى به عزت نفس \\
\hline$\cdot 1 \cdot \cdot 1$ & $r / 9$. & $\cdot / r$ & $\cdot / r 1$ & مسير برونكر ايى به عزت نفس \\
\hline.$/ \cdot 1$ & $9 / 1 \mathrm{~V}$ & $\cdot / \Delta \Delta$ & $\cdot / 4 q$ & مسير خوشايندى به عزت نفس \\
\hline.$/ \cdot 1$ & $9 / 4 \wedge$ & $\cdot / \pi r$ & $\cdot / \mathrm{AV}$ & مسير عزت نفس به تاب آورى \\
\hline$\cdot \cdots \Delta$ & $r / v \wedge$ & $\cdot / 10$ & $\cdot / \Upsilon \Lambda$ & مسير وظيفه شناسى به تاب آورى \\
\hline$\cdot / \cdot 1$ & $9 / 09$ & $\cdot / r r$ & $\cdot 199$ & مسير برونكرايى به تاب آورى \\
\hline.$/ \cdot 1$ & $-f / \cdot V$ & $-\cdot / 49$ & $-\cdot / \Delta \Delta$ & مسير روانرنجورخويى به تاب آورى \\
\hline
\end{tabular}




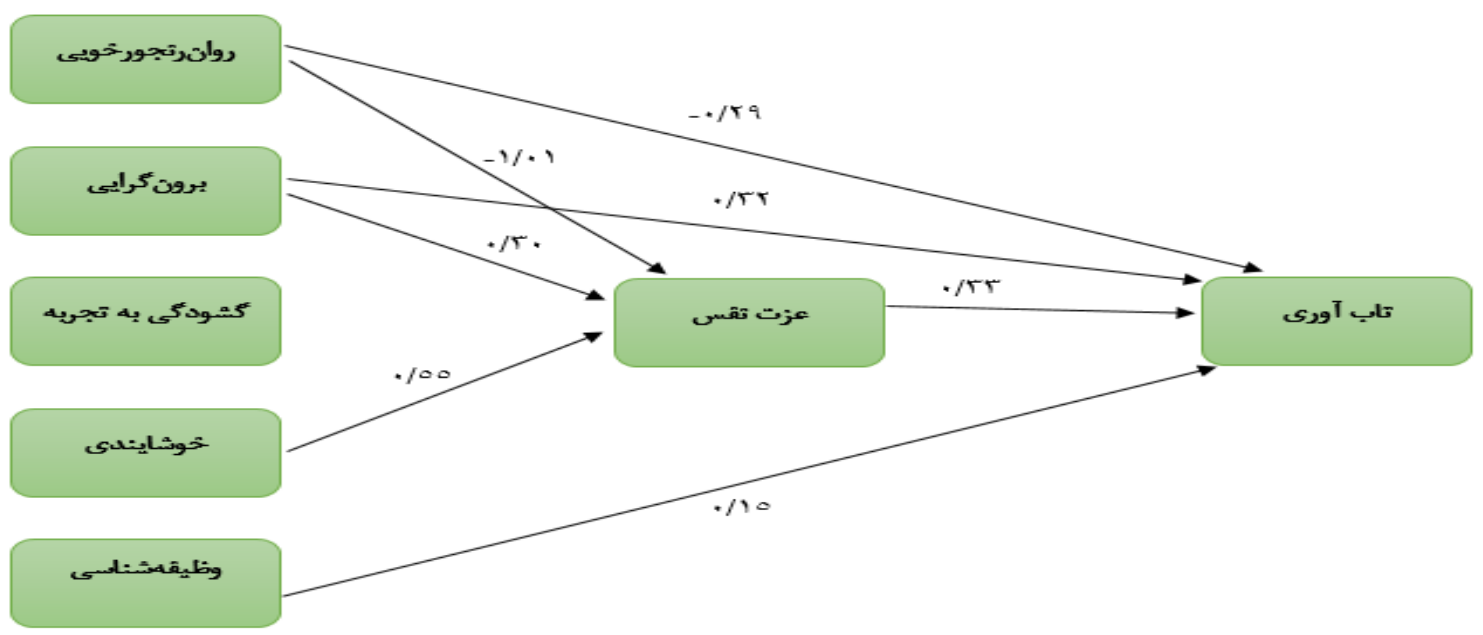

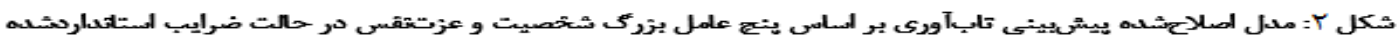
, ركروسيون

تاب آورى فقط از طريق روانرنجورخويى، برونگرايى و وظيفه شناسى مستقيماً قابل بيشبينى است. عزت نفس نيز

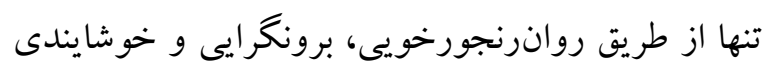
قابل بيشينى است. به منظور دركك بهتر اثرات مستقيم، غيرمستقيم و كل هر يك از متغيرها، نتايج مربوطه به طور كامل در جدول ه نمايش داده شده است.
همانطور كه در جدول F و مدل اصلاحشده در شكل r r ماهده مشاهده مىشود، از ميان ابعاد شخصيتى فقط روانرنجورخويى و برونگرايى اثر مستقيم و غيرمستقيم بر

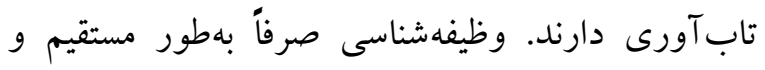
خوشايندى نيز صرفاً بهطور غيرمستقيم بر تابآورى اثر

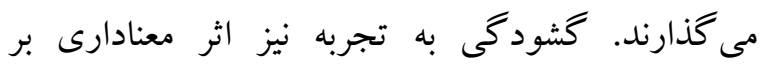
عزتنفس و تابآورى نداشته است. به طوركلى،

\begin{tabular}{|c|c|c|c|c|}
\hline متغير ملاكى & اثر كل & اثر غير مستقيم & اثر مستقيم & متغير ويشبين \\
\hline تاب آورى &.$- / 94$ & $-\cdot / \pi$ & $-\cdot / 7 q$ & روانرنجورخويى \\
\hline تاب آورى & d / FY & $\cdot /$. & . & برونكر ايى \\
\hline تاب آورى & $\cdot / 11$ & $\cdot / 11$ & - & خوشايندى \\
\hline تاب آورى & .110 & - &.$/ 10$ & وظيفه شناسى \\
\hline عزت نفس & $-1 / \cdot 1$ & - & $-1 / \cdot 1$ & روانرنجورخويى \\
\hline عزت نفس & $\cdot / \mu$. & - & $\cdot / \mu$. & برونكرايى \\
\hline عزت نفس & $\cdot / \Delta \Delta$ & - & $\cdot / \Delta \Delta$ & خوشايندى \\
\hline تاب آورى & 每 & - & 每 & عزت نفس \\
\hline
\end{tabular}

بزر گترين اثر كلى بر تابآورى است. همجنين، برون-

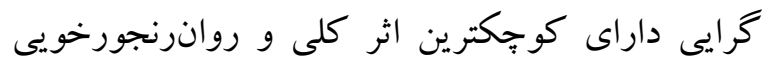

همان گونه كه در جدول هـ مشاهده مىشود، وظيفه شناسى داراى كوجّترين اثر كلى و روانرنجورخويى داراى 
واريانس عزتنفس توسط عوامل شخصيت تبين شده است. در ادامه شاخصهاى برازش مدل اصلاحشده در

$$
\text { جدول } 9 \text { ارائه گرديده است. }
$$

داراى بزركترين اثر كلى بر عزت نفس است. در يايان، لازم به ذكر است كه مدل اصلاحشده ئزوهش توانسته

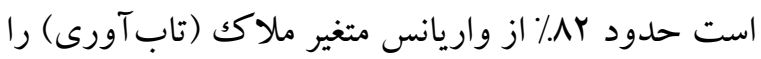
تبيين كند. علاوه بر اين، در مطالعه حاضر، حدود سو٪ از

\begin{tabular}{|c|c|c|}
\hline مقدار مشاهدهده شده & نقطه برش & شاخص برازش 9. \\
\hline.$/ 91$ & $>\cdot / 9$ & GFI \\
\hline $1 / \cdot \cdot$ & $>.19$ & CFI \\
\hline.$/ 91$ & $>\cdot / 9$ & RFI \\
\hline.$/ 99$ & $>.19$ & TLI \\
\hline$\cdot / \cdot r$ & $<\cdot / \cdot 1$ & RMSEA \\
\hline
\end{tabular}

و سادوك (Y.VV) همسو است. در تبيين نتايج فوق مىتوان كفت از آنجايى كه ويز گیىهاى شخصيتى مثبت ازجمله وظيفه شناسى، خوشايندى، گشود گى به تجربه و برون گرايى معمولاً با تجربه هيجانات مثبت و دريافت بازخوردهاى مثبت از سوى ديخران همر اهاند، مىتواند سطح عزت نفس و تاب آورى فرد را بالا برده و آسيبذيذيرى وى را نسبت به انواع مشكلات روانى و ورك جسمانى كاهش دهند؛ يعنى همانطور كه بنتى و

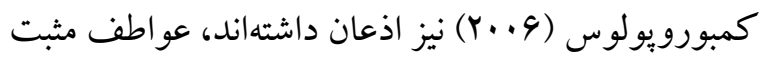
همبستخى مثبت و عو اطف منفى همبستخى منفى با عزت

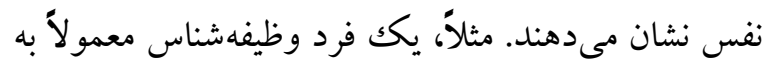
واسطه نظم، مسئوليت يذيرى، هدفمندى، جديت در انجام وظايف و كسب موفقيتهاى تحصيلى و شغلى، علاوه بر آن كه مورد تأييد و تحسين ديخران قرار مى گيرد، شانس آن را دارد كه هيجانات مثبتى جون شادى و غرور را نيز بيشتر از افراد عادى تجربه كند. بعلاوه، جنين فردى به تهريه دليل بشتكار و خود انضباطى بالا، عليرغم وجود موانع و

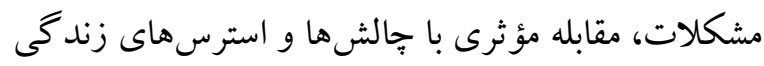

همانطور كه در جدول 9 مشاهده مىشود، مقدار شاخص RMSEA شاخصهاى CFI ، TLI ،GFI و RFI نزديك به 1 و بيشتر از نقطه برش •9/ • است؛ بنابراين با توجه به كليه شاخصهاى برازش مىتوان نتيجه گرفت كه مدل اصلاح شده يزٔوهش دار ايى برازش مناسبى با دادهها است. يثروهش حاضر به منظور بررسى نقش واسطهاى عزتنفس در رابطه ميان ينج عامل بزرگك شخصيت و تابآورى انجام شد. نتايج نشان داد كه تابآورى و عزتنفس با وظيفهشناسى، خوشايندى، گشود

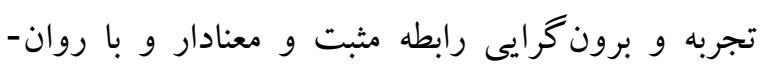
رنجورخويى رابطه منفى و معنادار دارند. نتايج مذكور با مبانى نظرى و يافتهاى يثوهشى ازجمله اوشيو، تاكو،

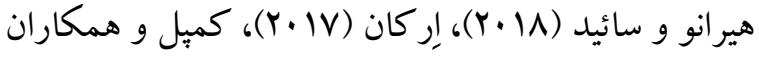

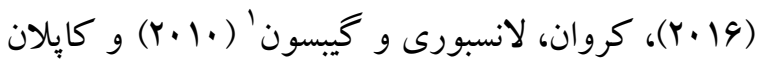

\footnotetext{
1- Kirwan, Lounsbury \& Gibson
} 
ناساز گارانه ازجمله روانشناختى بالا معمولاً با تجربه مكرر و شديد هيجانات منفى، خشم و كينهتوزى، فرسودگى هيجانى و دريافت بازخوردهاى منفى از سوى ديخران همراهاند، مىتوانند از طريق ايجاد اضطراب، خشم، ناكامى، نااميدى و باورهاى منفى، سطح عزت نفس و تاب آورى فرد را كاهش داده و وى را نسبت به به به انواع مشكلات روانى و جسمانى آسيب يذير گردانند. همانگ گونه كه در بخش نتايج مشاهده شد، مدل اوليه يُزوهش، برازش لازم را با دادهها نداشت؛ ازاينرو، مدل اوليه براى بيشبينى تابآورى، با حذف مسيرهاى غير بروني

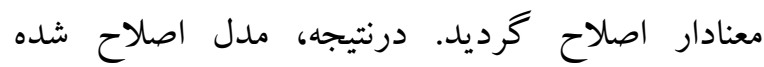

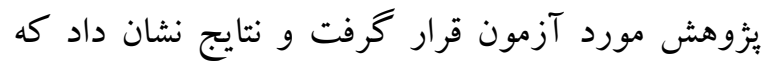
مدل مزبور برازش قابل قبولى با دادهها دارد. مطابق با مدل اصلاح شده، عزت نفس فقط در رابطه روانرنجورخويى، برونكرايى و خوشايندى با تابآورى نقش واسطهاى دارد. يافته مذكور را مىتوان تا حدودى مشابه با نتايج مطالعات كوان و همكاران (Y.IV) و شى و همكاران

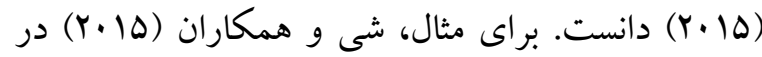
يثزوهش خود نشان دادند كه عزت نفس در رابطه بين خوشايندى، گشودگى به تجربه، روانرنجورخويى و و علائم افسردگى، نقش واسطهاى دارد. كوان و همكاران نيز عزتنفس را متغيرى مىدانند كه بين صفات (Y. V V) شخصيتى و رضايت از زندكى مداخله مى كند. در تبيين اين يافته مىتوان گفت كه ويز گیىهاى شخصيتى مثبتى جون برونگرايى و خوشايندى به وسيله تقويت عزتنفس سيرى در برابر بيامدهاى ناكوار استرس ايجاد مى كنند كه اين مسئله نهايتاً موجب افزايش سطح تاب آورى فرد مىشود. براى مثال، از آنجايى كه افراد داراى سطوح بالاى خوشايندى در ارتباط با ديخران
دارد و پِس از شكست و ناكامى به راحتى دجار دلسردى و ناميدى نمىشود. يكك فرد خوشايند يا موافقت جو علاوه بر آن كه كمتر درگير كينه ورزى، دشمنى و انتقامجويى است، به واسطه سادگى، تواضع، مهربانى و فداكارى غالباً مورد توجه و ستايش ديخران نيز قرار مى بـ كيرد و به اين خاطر هيجانات منفى را به ندرت تجربه مى كند. علاوه بر اين، به واسطه كمككرسانى به ديخران معمولاً حس ارزشمندى و مولد بودن را تجربه مى كند. يكك فرد كشوده نيز به واسطه تنوع تجارب و بهره كيرى از خلاقيت بالاى خود در حل مسائل و رويارويى با جالشها، شيوههاى مؤثرى براى مقابله با استرسها و ناگوارىها به كار مى گيرد كه اين شيوههاى مؤثر در نهايت عزت نفس و تاب آورى وى را بالا مىبرند. فرد برون گرا نيز به واسطه علاقهمندى به جمع، گرايش به

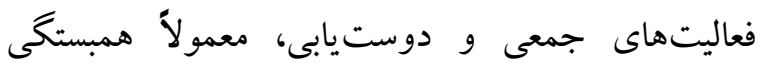
بالايى با اجتماع مىيابد كه اين همبستكى احتمال طرد،

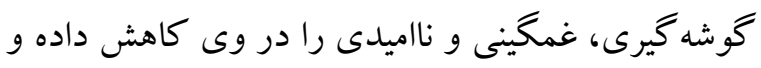
زمينه ساز تجربه هيجانات مثبت و رويدادهاى انرزى بخش مى گردد. در مجموع، اين گونه مىتوان گفت كه تجارب و هيجانهاى مثبت در افراد داراى ويزگ گهى شخصيتى مثبت و ساز گارانه، توان تغيير دادن، تعديل كردن يا كاهش دادن نتايج منفى و مصيبت بار را تقويت كرده و سطح عزت نفس و تاب آورى افراد مذكور را افزايش مىدهند. همجنين، در راستاى تبيين نقش

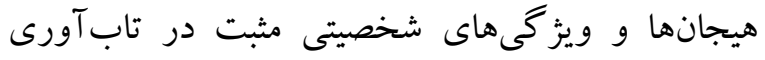
مى توان اين نكته را يادآور شد كه در شرايط استرسزاى شديد اين ويزگىها موجب آرميدگى روانشناختى و

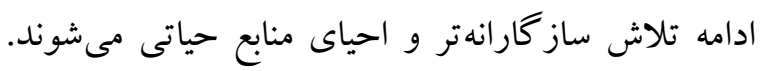
در مقابل، ازآنجايى كه ويز گیىهاى شخصيتى منفى و 
جالشها و مشكلات پِيين آمده و تابَآورى آنان در برابر سختىها و استرس ها كاهش مى يابد.

\section{نتيجه تيرى}

براساس نتايج حاصل از يُزوهش، توجه به متغيرهايى جون

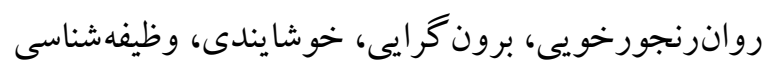

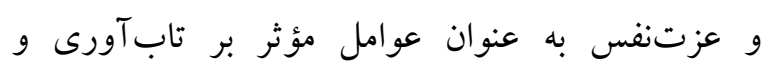
همجنين توجه به عزت نفس به عنوان ميانجى رابطه روان

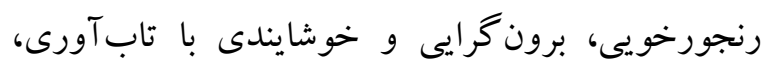
مى تواند به درك بيشتر رابطه ميان متغيرهاى مذكور بينجامد. در واقع، با توجه به يافتهاى ئزوهش حاضر نقش عزت نفس در اتصال صفات شخصيتى به تاب آورى، بسيار بر جسته مىشود؛ بنابراين، از آنجايى كه تحقيقات نشان دادهاند كه صفات شخصيتى تغييريذيرى بايينى دارند، شايسته است كه جهت افزايش سطح تابآورى افراد آسيب يذير و دجّار ضعف هاى شخصيتى، تمركز را بيشتر بر روى عزت نفس آنان كذاشت تا با تقويت كردن آن، از تأثيرات منفى عوامل شخصيتى بر تابآورى اين افراد كاست. بر اين اساس، اهميت

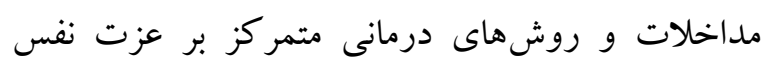

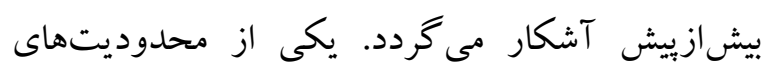

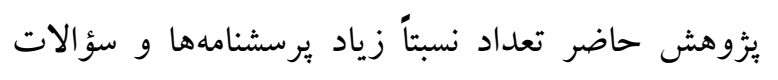
آنها بود كه اين امر مىتواند شر كت كنند كان را خسته و

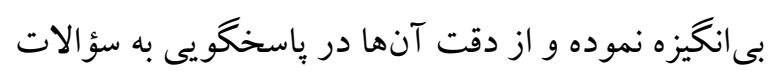

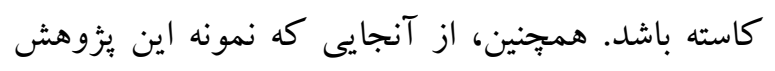

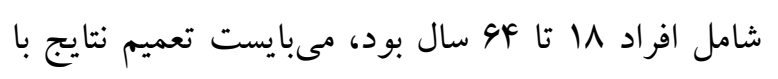

$$
\text { احتياط بيشترى صورت بخيرد. }
$$

سياسگز ارى
همدلى بيشترى نشان مىدهند و نسبت به آنها خوشبين و با اعتماد هستند؛ بنابراين دوستداشتنى تر به نظر مى آيند و تأييد و حمايت اجتماعى بيشترى دريافت مى كنند كه

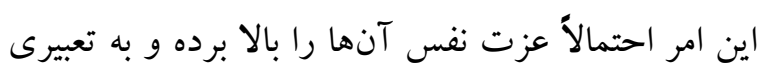
حس ارزشمند بودن را به آنها القا مى كند. افزايش عزت نفس نيز به نوبه خود آنها را يارى مىدهد كه با تجارب استرسزاى زندگى به نحو مؤثرترى كنار بيايند. افراد

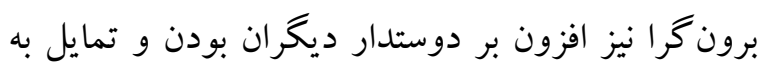

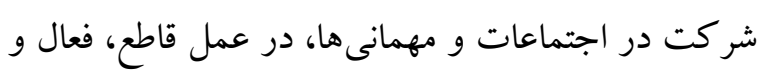
يرحرف يا اهل كفتگو هستند. يكك مطالعه نسبتاً جديد نيز نشان داده است كه برون گرايى بيشتر، خلق مثبت بيشترى

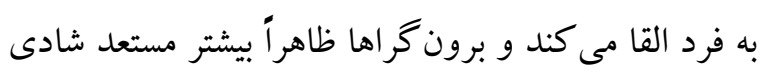
و هيجانات مثبت هستند (كروان، لانسبورى و كيبسون،

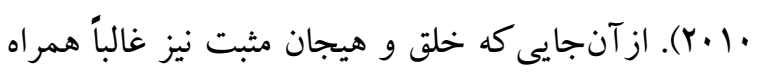
با افكار و باورهاى مثتى درباره خود است، مىتواند به تقويت عزت نفس فرد كمك نموده و از اين طريق احتمال ايستادگى بيشتر او را در برابر سختىها و و ناملايمات زندكى افزايش دهد. از طرف ديخر با توجه به اينكه عامل روانرنجورخويى بهطوركلى بيانگر هيجانات منفى است، در افرادى كه سطح اين عامل بالا

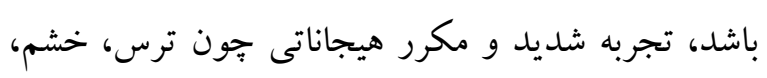

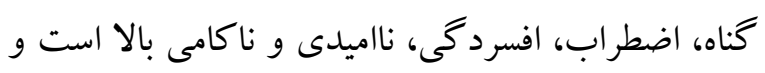
در نتيجه اين عوامل، عزت نفس يا حس ارزشمندى جنين

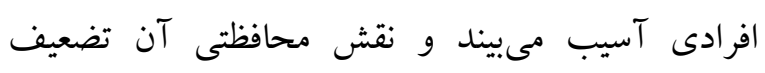
مىشود. افراد دجار عزت نفس بِيين نيز معمولاً انتقادنايذير بوده و ناتوان از كمككخواهى هستند و نياز خود به احترام ديدن و موردتوجه بودن و نيز تمايلات جنسى خويش را سركوب مى كنند (يانگز و همكاران،

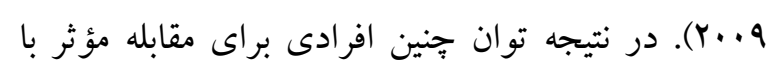


of exchange students in Russia. Intemational Journal of Intercultural Relations, 31, 181-197.

Huczynski A, Buchanan D. (2013). Organizational behavior: an introductory text (8th Edition), New York: Pearson Education.

Johar SS, Ishak MS, Zainudin A. (2013). Neuroticism personality and emotional intelligence of leader, and impact towards self-esteem of employee in organization. Procedia - Social and Behavioral Sciences, 84, 431-436.

John OP, Naumann LP, Soto CJ. (2008). Paradigm shift to the integrative Big Five trait taxonomy: History, measurement, and conceptual issues. In O. P. John, R. W. Robins, \& L. A. Pervin (Eds.), Handbook of personality: Theory and research (p. 114-158). The Guilford Press.

Kirwan J, Lounsbury J, Gibson L. (2010). Self-direction in learning and personality: The Big Five and narrow personality traits in relation to learner self-direction. International Joumal of SelfDirected Learning, 7, 21-34.

Kwan VSY, Bond MH, Singelis TM. (2017). Pancultural explanations for life satisfaction: Adding relationship harmony to self-esteem. Journal of Personality and Social Psychology, 73, 1038-1051.

Lai DWL, Qin N. (2018). Extraversion personality, perceived health and activity participation among community-dwelling aging adults in Hong Kong. PLoS ONE 15(1): e0227896.

Lazarus RS. (1993). From psychological stress to the emotions: A history of changing outlooks. Annual Review of Psychology, 44, $1-21$.

Liu Y, Wang Z, Zhou C, Li T. (2014). Affect and selfesteem as mediators between trait resilience and psychological adjustment. Personality and Individual Differences, 66, 92-97.

Luk CL, Yuen JLC. (1997). The role of self-concepts of technical school students in their learning of a second language. Psychologia: An International Journal of Psychology in the Orient, 40, 227-232.

Mc Crae RR, Costa PT. (1987). Validation of the fivefactor model of personality across instruments

$$
\begin{aligned}
& \text { از تمامى شهروندان محترم منطقه } 9 \text { شهردارى تهران كه } \\
& \text { مشاركت در يُزوهش حاضر را خالصانه يذيرفتند، به ياس } \\
& \text { همكارى و همراهى كمال تشكر و قدردانى را داريم. }
\end{aligned}
$$

\section{References}

Asvadi-Kermani I, Ashraphian P, Zeinali S, Imani M, Shabanloei R. (2010). A Study of Cancer Patients' Personality Profile and its Comparison with that of Normal Persons. Avicenna J Clin Med, 16(4), 26-30. [In Persian].

Benetti C, Kambouropoulos N. (2006). Affectregulated indirect effects of trait anxiety and trait resilience on self-esteem. Personality and Individual Differences, 41, 341-352.

Bonanno GA. (2014). Loss, Trauma, and Human Resilience. Have We Underestimated the Human Capacity to Thrive After Extremely Aversive Events? American Psychologist, 59(1), 20-28.

Cai H, Wu Q, Brown JD. (2009). Is self-esteem a universal need? Evidence from the People's Republic of China. Asian Joumal of Social Psychology, 12, 104-120.

Campbell-Sills L, Cohan SL, Stein MB. (2016). Relationship of resilience to personality, coping, and psychiatric symptoms in young adults. Behav Res Ther, 44(4), 585-599.

Costa PT, MoCrae RR. (1992). Normal personality assessment in clinical practice: The NEO Personality Inventory. Psychological Assessment, 4(1), 5-13.

Ercan H. (2017). The Relationship between Resilience and the Big Five Personality Traits in Emerging Adulthood. Eurasian Joumal of Educational Research. 17, 1-22.

Farber EW, Schwart J AJ, Schaper PE, Moonen DJ, McDaniel JS. (2010). Resilience factors associated with adaptation to HIV disease. Psychosomatics, 41, 140-146.

Galchenko I, Van DeVijver FJR. (2017). The role of perceived cultural distance in the acculturation 
and observers. Journal of Personality and Social Psychology, 52(1), 81-90.

Mc Crae RR, Costa PT. (1999). A five factor theory of personality. In L. A. Pervin (Ed.), Handbook of personality: Theory and research (pp. 139153). New York: Guilford Press.

Oshio A, Taku K, Hirano M, Saeed G. (2018). Resilience and Big Five personality traits: A meta-analysis. Personality and Individual Differences, 127, 54-60.

Park J, Kim Y, Park S, Suh A, Lee H. (2016). The relationship between self-esteem and overall health behaviors in Korean adolescents. Health Psychology and Behavioral Medicine. 4, 175185.

Pervin LA. (2003). The Science of Personality, Second Edition. Oxford University Press.

Rezaei T, Bayani A, Shariatnia K. (2015). The prediction of mental health based on variables of self-esteem, life satisfaction and hope among college students. Iran J Health Educ Health Promot. 3(3), 242-252. [In Persian].

Richardson GE. (2002). The meta-theory of resilience and resiliency. J. Clin. Psychol, 58, 307-321.

Robins RW, Tracy JL, Trzesniewski K, Potter J, Gosling SD. (2011). Personality correlates of self-esteem. Journal of Research in Personality, 35, 463-482.

Rosenberg M. (1965). Society and the adolescent selfimage. Princeton, NJ: Princeton University Press.

Shi M, Liu L, Yang Y, Wang L. (2015). The mediating role of self-esteem in the relationship between big five personality traits and depressive symptoms among Chinese undergraduate medical students. Personality and Individual Differences, 83, 55-59.

White B, Driver S, Warren AM. (2010). Resilience and indicators of adjustment during rehabilitation from a spinal cord injury. Rehabil Psychol, 55(1), 23-32.

Yu X, Zhang J. (2007). Factor analysis and psychometric evaluation of the Connor Davidson Resilience Scale (CD-RISC) in Chinese people. Social Behavior and Personality, 35, 19-30.
Zhang CM, Zou H, Xiang XP. (2006). The relationship between self-esteem and personality of high school students. Chinese Mental Health Joumal, 20, 588-591. 